I cannot help wondering what Danish readers will make of that phrase sthe sacred core of wisdom of another culture «. I have no reason to suppose that Borish uses this rather unfashionable formula carelessly or without thought. As one who also looks at Denmark from outside, though from a less geographical and cultural distance I find it both illuminating and moving. I hope that this book will encourage many, both inside and outside Denmark, to consider more deeply the particular qualities of Danish society which the author has found to be of such value and significance; and the all-pervading influence of Grundtvig in them. There can be no doubt that these qualities are threatened at the present time by the possibility of what Borish summarizes in the phrase "the Germanization/Thatcherization/Americanization of Denmark «. That is all the more reason for trying to see more clearly what exactly those qualities are and how they may be strengthened in Denmark and acknowledged more widely in the outside world.

\title{
Om Guds datter i folkehøjskolen
}

\section{Af William Michelsen}

Midt $i$ højskolen. En antologi om det folkelige, det politiske, det universelle og det historisk-poetiske. Udgivet $i$ anledning af Foreningen for Folkehøjskolers 100 års jubiloum. Redaktion Else-Marie Boyhus. Gyldendal 1991. 269 sider.

Lad det være sagt straks. Det er en prægtig bog, Højskolebladets redaktør i samarbejde med foreningens formand Ove Korsgaard her fejrer foreningens 100 års-jubilæum med. Den er værd at læse og gennemarbejde for enhver, der arbejder med Grundtvigs tanker og i Grundtvigs spor. Lidt over halvdelen af dens 10 forfattere har akademisk baggrund, resten har deres baggrund $i$ den grundtvigske højskole - den, der voksede frem som resultatet af Grundtvigs tanker om og arbejde for »Skolen for Livet«. Sådan var det også med dem, der skabte de første folkehøjskoler. De fleste var akademikere, der brød ud af den akademiske tradition for at lære menigmand at forstå sig selv og blive skikket til at deltage i det politiske liv. Hvilket er blevet et forbillede for andre folk, i endnu højere grad i dag end nogensinde før.

Bogen er en samling artikler af meget forskelligt indhold og længde, fordelt i 3 afsnit med en indledning af Ove Korsgaard og en slutning af Ejvind Larsen, og det er denne sidste artikel, der har givet anledning til, at Grundtvig-Studier har fået bogen tilsendt til anmeldelse. Men hele bogen, ikke mindst Ove Korsgaards indledning, »Højskolen til debat «, er gennemsyret af Grundtvigs tanker, hvilket har fået det fornøjelige udtryk, at den er illustreret af tegninger fra dette århundrede, der alle forestiller Grundtvig selv, sådan som tegnerne har forestillet sig ham. De viser, hvor forskellige forestillinger eftertiden har gjort og gør sig om denne usædvanlige mand, som samtiden enten blev grebet af eller vragede, 
snart frygtede og snart lod som om de var ligegyldige over for. Bogen viser, hvor mange og hvor forskellige tanker, Grundtvig stadig vækker. Men det er kun i den sidste, man møder Grundtvig selv, set fra nutidens synspunkt.

Ove Korsgaards indledning beskriver den udvikling, der har fundet sted indenfor højskolebevægelsen siden 1961, da bogen »Højskolen til debat « udkom, præget af »de såkaldte Asperupmøder, der gennem en længere årrække blev afholdt i Båring Præstegård hos Kaj Thaning «. De har ifølge Ove Korsgaard haft »uhyre stor, næsten mytologisk betydning for det højskolesyn, der materialiserede sig i oprettelsen af Båring Højskole i 1959, og som dominerede efterkrigstidens højskole - frem til 1968«, båret af Kaj Thanings Grundtvig-fortolkning: „Højskolen skal ikke bygge på et kristent livssyn og ej heller rode kristendommen ind $\mathrm{i}$ alle borgerlige anliggender. Skolens opgave er ikke at give folk kristen tro, men at give oplysning om menneskelivet og folkelivet.« - At dette var Grundtvigs hensigt med at udkaste tanken om »en folkelig Højskole«, kan der efter min mening ikke være nogen tvivl om. Men dermed har jeg ikke sagt, at Grundtvig havde ændret sin egen livsanskuelse og sin kristne tro, da han første gang udkastede tanken i indledningen til Nordens Mythologi 1832. Sagen er efter min mening, at Grundtvig ønskede at adskille sin kristne tro og livsanskuelse fra dén videnskabelige og politiske debat, som burde ligge bag ved og udfolde sig på en virkelig "Skole for Livet «, som skitseres i hans lille bog med denne titel et par år senere. Men herom har jeg ikke kunnet blive enig med Thaning. - Det vedkommer imidlertid ikke den udvikling, som Thanings tanker har sat i gang inden for den danske folkehøjskole og langt uden for Danmark. Der er næppe tvivl om, at det er højskoletanken, der har fået størst betydning af alle Grundtvigs tanker i dette århundrede. - Det er denne udvikling, der skildres i Ove Korsgaards indledningsartikel.

Det mest påfaldende og grundigst beskrevne eksempel i denne bog på udviklingen af Grundtvigs højskoletanke er sikkert Henrik Ydes artikel om Martin Andersen Nexø og Weimar-republikkens højskolebevægelse i Tyskland. Den har fået overskriften »Gesandt for Grundtvig « og er et koncentrat af et stort afsnit i Ydes disputats "Det grundtvigske i Martin Andersen Nexøs liv«. Artiklen her er mindst lige så fængslende og velskreven som afsnittet i disputatsen.

Artiklerne er i det hele taget skrevet, som om de var tænkt til brug for foredrag på en virkelig højskole af den art, som Grundtvig ønskede sig: ikke videnskabelige forelæsninger af den art, som kun kunde forstås af specialister med sproglig eller matematisk særuddannelse og i et videnskabeligt kunstsprog, men grundige og gennemtænkte foredrag i et forståeligt dansk sprog. Grundtankerne er fremhævet i overskrifterne: "Det er det politiske, der binder sammen« (af Else-Marie Boyhus, bogens redaktør), »Historiens fælde værens fylde «, en gådefuld titel af Ole Jensen, med undertitlen »Mellem håbløshed og håb«. Så er in teressen vakt. Askov Højskoles forstander Hans Henningsen skriver om »Det folkelige og Europa«. Så ved vi, hvor vi er. To artikler om »Kropsfagene i højskolen « af Frederik Christensen og Claus Bøje har fået stikordet "Det uformulerbare «. Og en artikel af Lars Bo Bojesen om de psykologiske fag i højskolen har fået overskriften »Sjælen og ånden«. Denne titel er ægte grundtvigsk. Om tankerne er det, er et andet spørgsmål. Men det var ikke det, Grundtvig ønskede 
de skulde være - selv om han ikke selv kunde undgå at tænke grundtvigsk, når han talte og skrev, en sjælden gang også talte på en højskole.

Den sidste artikel "Folkestyrets mystik " af Ejvind Larsen, har fået undertitlen »Den danske folkehøjskole, andelsbevægelsens tredje vej og Guds datter Sofia«. Det var en stor mundfuld - og det er det også, når man kommer til teksten selv. Den handler nu ikke så meget om andelsbevægelsen og folkehøjskolen, men des mere om de digte fra Grundtvigs sene år, hvor han taler om "Guds Datter " og undertiden (i de allerseneste digte) om brylluppet mellem "Guds Datter« og Guds Søn.

Det er dog ikke dér, artiklen begynder. Pointen er den, at Grundtvig i 1861, da han genudgav sine »Optrin af Nordens Kæmpeliv« I-II, som er digtet før det kristne gennembrud i 1810 og udgivet i 1809 og 1811, foretog nogle små ændringer i teksten, som Ejvind Larsen - i og for sig med rette - undrer sig over, at Grundtvigforskningen ikke tidligere har fordybet sig i. Hans undren skyldes, at Grundtvig dér indfører ordet "Visdom«, på græsk »Sophia «.

Skulde Grundtvig allerede her, syv år før han i en tale på „Vennemødet« $i$ København talte om »den himmelske Faders Datter «, have forestillet sig, at denne »Guds Datter «, der skulde opdrages her i Norden, »i et andet lille helligt Land« (»ligesom han opdrog hans Søn i de galilæiske Egne«) have forestillet sig noget lignende, som når den østlige kirke forestillede sig "Sophia « som Guds datter og indviede hovedkirken i Konstantinopel til hende? - Ejvind Larsen nøjes med at antyde tanken som et spørgsmål, og det er godt. For Grundtvig bruger ikke ordet eller navnet Sophia på nogen af de steder, han citerer fra Grundtvigs digte. Men derfor kan man jo godt stille det spørgsmål: hvad forestillede Grundtvig sig, når han i sine sene digte brugte udtrykket "Guds Datter«? Spørgsmålet er faktisk besvaret i kommentaren til i hvert fald et af disse digte: det er Kirken, Grundtvig her har forestillet sig.

At Grundtvig så at sige skulde have indsmuglet en kvindelig guddom i Jomsborg, når han lader den kristne Odinkar sige til jomsvikingen Vagn Aagesen, der vægrer sig ved at tro, at Jesus skulde have knust den Ondes (Slangens) hoved:

Vist er det knust, vi nu som Overmænd

Den Trædske kan med Visdom overvinde...

simpelthen fordi han her indfører ordene "med Visdom«, det forekommer mig usandsynligt. - Ejvind Larsen har ret i, at Odinkars svar til Vagn Aagesen er radikalt ændret på dette sted. Men det er der ingen grund til at undre sig over. Når Grundtvig i 1811 kunde foretage en radikal ændring i værkets (ifølge planen) første del »Norners og Asers Kamp« i overensstemmelse med sit kristelige gennembrud i 1810, er det kun naturligt, at han i 1861 ændrer dette sted i den (ifølge planen) sidste del i overensstemmelse med sin nuværende kristendomsopfattelse. Men hermed er ikke sagt, at Grundtvig her skulde være optaget af den $\emptyset$ stlige kirkes Sophia-mystik.

Det sted i Grundtvigs sene digtning, hvor Grundtvig kommer denne mystik og dens kristne mytologi nærmest, er ifølge Ejvind Larsen digtet Dansk Ravnegalder fra 1860, som Grundtvig aldrig selv har ladet trykke. Ejvind Larsen citerer nogle verslinier heraf, lagt i munden på en hinduisk brahman, hvori det hedder, at han i Danmark har lært, at 


\author{
... Dansk Oplysning er med Skel \\ Et »Himmel-Lys« at nævne, \\ Saa himmelhøjt og soleklart, \\ At alle maa bekende, \\ Slet ingen Fingre uden Guds \\ Har dermed haft at gøre; \\ Det er en Søster billedlig \\ Til ham, som selv er Lyset, \\ Og har desaarsag kun paa Jord, \\ Som han, en Fosterfader, \\ Men har desaarsag og som han \\ Den kvindeligste Moder ...
}

En fuldstændig fortolkning af dette digt findes ikke. Det er trykt 1. gang i 1909 af Holger Begtrup (Udvalgte Skrifter bd. X s. 363-484), og han giver kun de sædvanlige korte oplysninger til læsningen af digtet. Men Ejvind Larsen afslører i en note, at hans artikel er et udkast til en større behandling af Grundtvig: »et forsøg på at vise, hvad det er for en Grundtvig, der tegner sig, når man tager ham selv alvorligt og så at sige fortolker ham fra slutningen.« - En sådan Grundtvig-fortolkning må vi altså have til gode. Men det hedder i en følgende note, at Grundtvig med de citerede linier »refererer ... til Sofias, Visdommens, præsentation af sig selv i kapitel 8 af Ordsprogenes Bog i Det gamle Testamente«. - At Grundtvig har kendt dette sted, er der ingen tvivl om. Men hvor meget af dette Grundtvig har læst på hebraisk, véd jeg ikke. Han læste hellere den gamle græske oversættelse eller dén danske, som Constance Leth havde foræret ham. Men i hvert fald ikke den, Ejvind Larsen citerer, fra 1871.

Studier over og fortolkninger af disse sene Grundtvig-tekster må man som Grundtvigforsker hilse velkomne, uanset om de forekommer moderne, umoderne eller post-moderne. Grundtvigs forfatterskab er langt fra udtømt. Det har ingen fare. Og man vil utvivlsomt dér finde store værdier. Der er ingen grund til at nære forlegenhed ved Grundtvigs såkaldte umodernitet, en forlegenhed, som Ejvind Larsen sporer i Grundtvig-Studier 1989-90. Det må dog være enhver Grundtvigforsker tilladt at ytre ikke blot sine meninger om, men også sine følelser ved Grundtvigs tanker! - Hovedsagen er at konstatere, hvad Grundtvig virkelig har forestillet sig, tænkt og sagt. Vurderingen deraf er en anden sag, der kan ændre sig med tiden, og som både i samtiden og eftertiden var og er omstridt.

Ejvind Larsen har med sine grundige studier over den sene Grundtvigs tanker om den kvindelige side af Guds væsen - ligesom i sin bog "Det levende Ord « - sat fingeren på et vigtigt punkt i Grundtvigs tanke- og symbolverden, som trænger til nærmere undersøgelser - i fortsættelse af det digt, der ligefrem har overskriften "Kvinde-Evangeliet « fra 1842 og begyndelsesordene: "I Herrens Huus er Varmen« (Grundtvigs Sang-Værk III nr. 205). Et væsentligt punkt, når Grundtvig taler om "Guds Datter «, er at få afklaret, om det er et eller flere mennesker, han herved tænker på, eller det er en side af Guds væsen, f.eks. visdommen. - Et lige så væsentligt punkt er, hvad Grundtvig forestiller sig ved ordet »Viisdom «, som han kan bruge i meget forskellig betydning, fx. »Verdens Viisdom«, som i hvert fald ikke er Guds. Men han kan også bruge det på lig- 
nende måde som ordet »Videnskab « i salmen »Vor Herres Jesu Mindefest « fra 1847:

En Videnskab, som Gud kun veed,

Er Livet i din Kiærlighed! (GSV IV, 168)

Kun ét sted - udover det fra 2. udgave (1861) af Optrin af Nordens Kæmpeliv anfører Ejvind Larsen, hvor Grundtvig bruger ordet "Viisdom« om den guddommelige visdom, nemlig det sidste digt, han anfører, som virkelig er højst bemærkelsesværdigt (GSV IV nr. 239). Det er en salme fra 1853, der handler om mennesket som skabt i Guds billede. Men kun ét sted i salmen forekommer ordet »Viisdom«, nemlig hvor det er Jesus som Guds billede, der tales om:

Jesus Christus er Jærtegnet,

Han er baade Gud og Mand,

Guddoms-Blivet med vor Tunge

I Guds Kraft udtaler han.

I hans Sjæl er Viisdoms Fylde,

I hans Bryst Guds Kiærlighed,

Og som han er, vi skal blive,

Derfor kom han til os ned.

Alt det Tabte det blev fundet

I vor Frelser, Davids Søn,

Hele Guddoms-Herligheden

$\mathrm{Nu}$ er Troens Naadeløn.

Det er altså i denne betydning, Grundtvig i 1861 lader Odinkar bruge ordene "... vi nu som Overmænd/den Trædske kan med Visdom overvinde «, dvs. med den visdom, som tillige med kærligheden er troens nådeløn. Sådan var nemlig Grundtvigs kristendomsopfattelse blevet igennem hans personlige religiøse udvikling, senest gennem salmesangen i Vartov, hvorom man kan læse hos Peter Balslev-Clausen, dels i Grundtvig-Studier 1989-90 s. 53-56, dels i hans bog "Det vingede ord «, 1991. - Om der derudover skulde ligge en indre forbindelse til den $\emptyset$ øtlige kirkes Sophia-mystik, er naturligvis ikke utænkeligt. Men Ejvind Larsen har endnu ikke fundet overbevisende vidnesbyrd derom.

Det er muligt, at forbindelsen simpelthen ligger i den faelleskristelige oplevelse af gudstjenesten $i$ alle de kristne kirker, i særdeleshed den kristne gudstjenestes kærnepunkt, nadveren. En oplevelse, der synes at være næsten helt udvisket $i$ den rationalistiske periode, men genoplivedes med den grundtvigske salmesang $\mathrm{i}$ Vartov. Herpå tyder fx. Arthur Macdonald Allchins foredrag Grundtvig Seen in Ecumenical Perspective, trykt som essay i Grundtvig-Studier 1989-90.

Det ejendommelige ved Ejvind Larsens artikel er imidlertid, at han ikke understreger den kirkelige side af Grundtvigs kristne menneskesyn, men i stedet fremhæver den betydning, dette syn har făet for udviklingen af højskoletanken, i særdeleshed gennem forestillingen om mennesket som et guddommeligt ekspe- 
riment $\mathrm{i}$ indledningen til Nordens Mythologi. - Hvis udviklingen i den danske højskole i 1961 gik bort fra kristendommen, går den altså hos Ejvind Larsen tilbage til kristendommen.

\section{Grundtvigs salmer og hans liv}

\section{Af William Michelsen}

Eva Meile: „Plant en lilje». Om Grundtvig og 3 af hans salmer. 48 sider, København, Unitas, 1992.

Dette lille studiehefte med omfattende litteraturhenvisninger viser, hvor stor interessen er for sammenhoengen mellem Grundtvigs salmer og hans personlige religiфse udvikling. Det er åbenbart ikke tilstrækkeligt at have de kendte biografiske oplysninger om Grundtvigs liv for at forstå blot de salmer, der står i salmebogen - for ikke at tale om i hans Sang-Værk og hans egne omarbejdelser og senere salmer. Vi trænger til et værk, der gennemgår hele Grundtvigs salmedigtning og hans liv.

\section{Det vingede ord}

\section{Af Hans Hauge}

Peter Balslev-Clausen: Det vingede ord: Om N.F.S. Grundtvigs salmedigtning. (Materialecentralen, København 1991) 143 sider.

Det vingede ord er ikke en oversigt eller gennemgang af Grundtvigs salmedigtning. Der er tale om naerloesning af udvalgte salmer begyndende med »De første salmer «, som første kapitel hedder. Når en bog indeholdende nærlæsning eller analyse af forholdsvis få salmer alligevel kan kaldes en bog om Grundtvigs salmedigtning, så er det, fordi Peter Balslev-Clausen i sin »Indledning « går ud fra noget, der må betegnes som en arbejdshypotese. Den går ud på, at Grundtvig livet igennem »vender tilbage til den samme inspiration og de samme motiver. Takket være denne kontinuitet i forfatterskabet er det muligt at få et indtryk af Grundtvigs grundlæggende tankestruktur (min understregning) (s. 9).« Man kan vel næppe kalde en sådan hypotese overraskende. Den kan se så tilforladelig ud, at man er tilbøjelig til at springe den over. Alligevel vil jeg mene, at Balslev-Clausen ved at fremsætte den, samtidig angiver, at han er ude på at gøre noget nyt eller anderledes i forhold til tidligere analyser af Grundtvigs salmer, som der jo er mange af. Hvad er så det nye, som Balslev-Clausen vil gøre, men som han ikke eksplicit siger, at han vil? Hvad er det, han er ude på 